\title{
Determinants of Onion Output Market Participation Level Among Smallholder Farming Households: The Case of Fentale District, Oromia Regional State, Ethiopia
}

\author{
TESFAYE TURA \\ Assistant Researcher at Ethiopian Institute of Agricultural Research, \\ Werer Agricultural Research Centre, Werer, Ethiopia
}

\begin{abstract}
This study focuses on analysing the factors affecting the decision and the level of onion output market participation among smallholder onion producers at Fentale district. Samples of 180 onion producer households were selected through multi-stage random sampling from three kebeles of Fentale district. The study employed both quantitative and qualitative methods of data collection. Quantitative data collected from sample households were analysed by descriptive and double hurdle model while qualitative analysed by narration. The result from the $1^{\text {st }}$ phase of the double hurdle, probit regression, revealed that sex of household head, onion farming experience, total farm holding, farm allocated for onion production, credit access, access to extension and market information were statistically significant and influence households onion market participation decision. The finding from the $2^{\text {nd }}$ phase of the hurdle model, truncated regression, show the age of household head, sex of household head, farm allocated to onion, irrigation access, number of oxen owned and distance to the nearest market were variables influencing smallholder onion market participation level and statistically significant. Finally it is recommended that the Government organizations and other responsible bodies should ensure the equal distribution of irrigation water for both upper and lower streams, strengthen inputs supply chains, and strengthen producers' cooperation.
\end{abstract}

Keywords: Double hurdle, Fentale, Market Participation, Onion, Smallholders

DOI: $10.7176 / \mathrm{JMCR} / 82-01$

Publication date:September $30^{\text {th }} 2021$

\section{INTRODUCTION}

Agriculture is the main economic pillars of the Ethiopian economy and the overall economic growth of the country is highly dependent on the success of the agriculture sector. The sector represents $42.7 \%$ of the GDP of the country and generates about $90 \%$ of the foreign exchange earnings of the country. Indeed, it supplies over $70 \%$ of raw materials for domestic industries and about $80 \%$ of the population gains their livelihood directly or indirectly from agricultural production (Alemu \& Berhanu, 2018; Nigussie et al., 2015).

However, Ethiopian agriculture is dominated by smallholder farming households in which $85 \%$ of households farming less than 2 hectares of farm while $40 \%$ of them are produce on less than 0.5 hectares of farm (Baltissen \& Betsema, 2016). The same Authors stated that high dependency on rain-fed, low fertilizer application rate, less wide-spread use of improved seed varieties as well as land degradation combined with continuously increasing population pressure leading to low level of production to meet the consumption requirement of the households.

Being one of the emerging fast growing economies in the world requires maximizing the potential of the agricultural sector and necessarily increasing the level of smallholders' agricultural productivity which is existed at the base level due to several socio-economic bottlenecks (Bedaso et al., 2012; Etafa, 2016). Among the main bottlenecks, poor access to inputs, poor irrigation system, poor technology, lack of adequate market price, and inadequate linkage between market actors and smallholders' farmers contribute to the low level of agricultural productivity in developing countries in general and Ethiopia in particular (Tilaye, 2010)

In Ethiopia, promoting the commercialisation of agricultural production is considered as a corner stone of the rural development and poverty reduction strategies of the government (Pender \& Alemu, 2007). Ethiopia has liberalized its economy and developed poverty reduction strategies that underpin market-led strategies for broad based agricultural development and economic growth (Boka, 2017). Policy makers view it as an essential component of agricultural modernisation, specialisation, and structural transformation of the economy towards more rapid and sustainable growth.

A farm household is assumed to be commercialized if it is producing a significant amount of cash commodities, allocating a proportion of its resources to marketable commodities or selling a considerable proportion of its agricultural outputs (Muricho et al., 2017; Poulton, 2018). According to Gebremedhin and Jaleta (2010) the meaning of commercialization goes beyond supplying surplus products to markets. It has to consider both the input and output sides of production, and the decision-making behaviour of farm households in production and marketing simultaneously.

Despite various agricultural policy reforms in Africa in general and in Ethiopia in particular, the majority of farmers are still subsistence oriented with a low level of participation in agricultural markets (Jaleta et al., 2009; 
Sokoni, 2008). Though the Government of Ethiopia sees the horticulture sector as one of the high priorities for export as well as the domestic market, its production is another subsistence farming practiced by smallholder farmers in Ethiopia and its cultivation is considered as supplementary to the production of main stable crops.

Smallholder farmers are the principal suppliers of fruits and vegetables which accounts for over $95 \%$ of the national production of the country (Gebreselassie, 2003). However, despite a long history of irrigated vegetables production, commercial production has expanded significantly since 2005 when national agricultural strategies began to favour the high value cash crops and productivity enhancement. In Ethiopia, Onion consumption is regular. It is important in the food seasoning and in daily stews called 'wots' as well it contributes to human health. The production of vegetables in general and onion in particular, has a comparative advantage particularly under conditions where arable land is scarce and labour is abundant. Onion production in the country is at an increasing rate both in farm area coverage and the amount produced (Agumas, 2019).

Understanding the extent of smallholder commercialization and its contributing factors, therefore, has important policy implications. However, smallholder farmers face many constraints that impede them from taking advantage of market opportunities (Fischer \& Qaim, 2012). Besides lack of marketing knowledge and skills to sell their products, the informal and inefficient supply chain arrangements in the traditional sub-sector provide low income and little incentives for growers and their families. This hinders them to improve their production and marketing activities and as a result, many of them often opt for lower prices at the farm gate or in the local markets (Gyau et al., 2016).

Output market participation decision and the level of participation of smallholders' onion producers are subject to combined effect of socio-economic, demographic and institutional factors in Ethiopia in general and at study area in particular. The study area, Fentale district, is one of potential areas for onion vegetable production which has a significant contribution to the livelihood of smallholder farmers of the area. Indeed, Onion contribute to enhance the income of the majority of smallholder producers as well ensures their food security.

However, despite the production potential and income contribution of the commodity, there is a dearth of study on onion commercialization status in Ethiopia in general and at the study area in particular. Most of the previous studies on the commercialization of smallholder farming in Ethiopia focus on grain crops like wheat, maize and teff (Alemu \& Bishaw, 2015; Ali et al., 2016; Bekele \& Alemu, 2015). On another hand, some others studies carried out in Ethiopia focused on the commercialization of horticultural crops as general without particular attention to vegetables in general and onion in particular (Tufa et al., 2014; Wondowussen \& Bekabil, 2014). Therefore, this study was conducted with the main purpose of analyse the factors determine the decision and level of the onion output market participation among smallholder onion producers at Fentale district.

\section{OBJECTIVES OF THE STUDY}

The objectives of the study were

- To analyse the determinants of the onion market participation decision among smallholders' farming households at Fentale district.

- To analyse the determinants of the onion market participation level among smallholders' farming households.

\section{SIGNIFICANCE OF THE STUDY}

Despite the increasing demand for the onion product both at inside and outside markets, smallholders' onion output market participation decision and the level of participation is affected both by external and internal factors. Clearly analyses these factors solve the supply shortage of onion product in one way and boost the income for onion producers on the other. Hence, the output of this study would be used as input which significantly help as firsthand information sources for policy makers, planners and development practitioners who primarily work to improve the livelihoods of smallholders' onion producers. 


\section{Conceptual Framework}

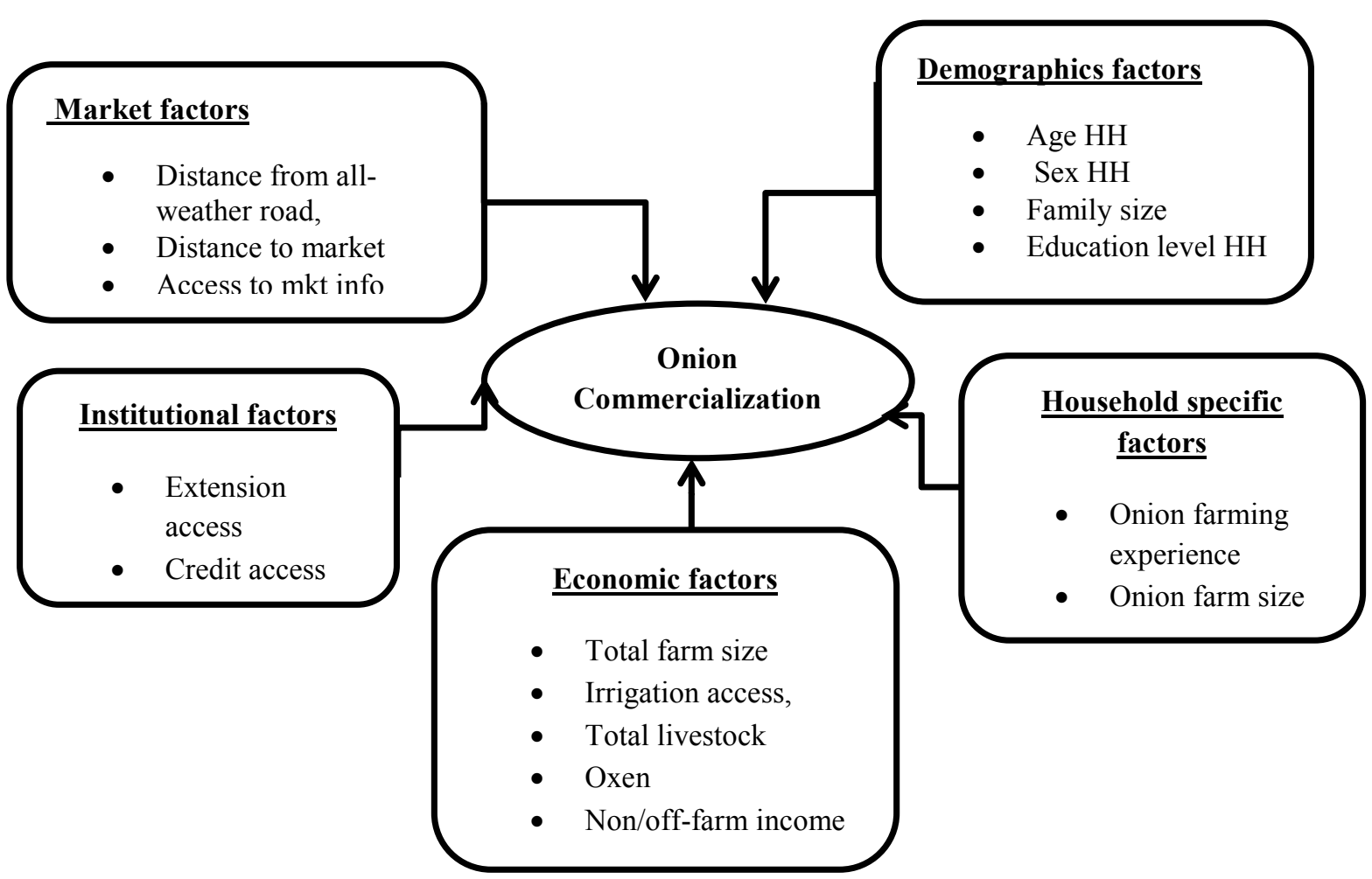

Source: adopted from Tozooney (2017) with modification

Figure: 1 Conceptual Frame work of the study

The framework indicated in figure 1 show the interrelationships between the key variables, both independents and dependent involved in the study. Those framed as independent variables are; Demographics factors (Age, sex, family size and education status of household head), Economic factors (Total farm size, irrigation access, total livestock owned (TLU), oxen and non/off-farm income), Institutional factors (access to extension and credit), Market factors ( distance to all weather road, distance to nearest market and market information) and Household specific characteristics (onion farming experience and farm land allocated to onion) expected to have either positive or negative influence on onion commercialization (onion output market participation).

\section{MATERIALS AND METHODS}

The study was conducted in Fentale district East Shoa zone, Oromiya regional State, Ethiopia. Multi-stage random sampling technique was employed for this study. At the first stage, Fentale district was selected purposively depend on its irrigation based onion production potential. At the second stage, out of eighteen kebeles of the district eight high potential onion producers' kebeles were selected and listed according to their onion production potential and irrigation access with consultation of the district Agriculture and Rural development experts. At the third stage, from eight onion producer kebeles, listed according to their onion production potential and irrigation access, the first three highest potential kebeles were selected purposively by considering the time factors and to ensure the efficiency of the study.

According to Fentale district pastoral and agro pastoral development office report, the total smallholder farm household of the three selected kebeles, Garadima, Gidara, and Alge were estimated to be 1000, 870 and 730 respectively (FWPADO, 2018). From the total farm households of the three kebeles which means 600 in total), the onion producers target population were estimated to be $60 \%$ of their respective numbers. So, according to calculation from Yamane formula the total sample size for the study was 180 onion producer smallholder households.

\section{Sampling Techniques}

To determine the sample size, the Yamane (1967) formula was employed. Expressed mathematically as;

$$
\mathrm{n}=\frac{\mathrm{N}}{1+\mathrm{N}\left(\mathrm{e}^{2}\right)}
$$

Where $\mathrm{n}$; represent the desired sample size, $\mathrm{N}$; represent the total onion producer households and e; represent the maximum acceptable margin of error which was set at $7 \%$ for this study. 
600,522 and 438 were the number of target population for three selected kebeles, Garadima, Gidara and Alge respectively which is totally 1560 . Accordingly, 180 total numbers of respondents selected from three kebeles by applied probability proportional to size. The following formula was applied to determine sample size for each three study kebeles

Respondent per kebele $=\frac{\text { Number of onion producers perkebele }}{\text { Total Onion producers of three kebeles }} *$ Sample size

Table.1 Sample size according to probability proportional to size

\begin{tabular}{cccc}
\hline Kebeles & Total HH & Onion producers HH & Sample Size \\
\hline Garadima & 1000 & 600 & 69 \\
Gidara & 870 & 522 & 60 \\
Alge & 730 & 438 & 51 \\
\hline Total & $\mathbf{2 6 0 0}$ & $\mathbf{1 5 6 0}$ & $\mathbf{1 8 0}$ \\
\hline
\end{tabular}

Source: Column 2 and 3 (FWPADO, 2018)

\section{Data Collection Methods}

For this study, both quantitative and qualitative data were collected by employed semi-structure interview schedule, and Focus Group Discussion (FGD) and Key Informant Interview (KII) respectively.

\section{Interview Schedule}

Interview schedule was employed to collect primary data by face to face contact with sample households through researcher administrated semi-structured questionnaires. The questions were forwarded to 180 sample household heads those randomly selected from the three rural kebeles, Garadima, Gidara and Alge of the study district.

\section{Focus Group Discussion}

The focus group discussion (FGD) was employed to collect qualitative data that help to strengthen quantitative data generated through interview schedule. The members of FGD composed both men and women those did not involve in the interview schedule. As the saturation of data existed the FGD limited to one at each sampled kebeles. The checklist prepared to guide the discussion on right track.

\section{Key Informant interview}

The primary data (both quantitative and qualitative) collected through Interview schedule and FGD were needed to be further enriched by additional information that gathered through Key informant interview (KII). Thus, intensive interview were conducted with key informants that comprise two experts from two different departments, horticulture and agronomy, one development agent (DA) and one committee member of farmers' cooperative from each sampled kebeles are included as a key informant interviewees. The qualitative data generated from KIIs were help to enrich the quantitative data collected through Interview schedule.

\section{Methods of data Analysis}

Quantitative data analysis was done through employed Statistical Package for Social Sciences (SPSS) version 22 and STATA version 14. Two step hurdle model was employed to analyse the market participation decision and level of participation. This was done by applied appropriate statistical methods. Descriptive statistics such as percentage, mean, standard deviation, graphs and tables were used to explain household characteristics like education status, age, sex, farm size, family size and farm size allotted for onion production. Besides, the qualitative data were analysed by content analysis, narrations, and interpretations of the meanings of words

\section{RESULT AND DISCUSSION}

Socioeconomic Characteristics of sample households

Table 2 and 3 below presents the descriptive result of continuous and dummy variables of the respondents respectively. The sample population of onion producer respondents those contacted during the survey was 180 . Regarding to marital status, out of the total sample households $81 \%$ was married while $7.4 \%, 6.3 \%$ and $5.3 \%$ was widowed, single and divorced receptively. 
Table 2 Results of descriptive statics for continuous variables

\begin{tabular}{|l|c|c|c|c|c|}
\hline Variables & Obs & Mean & Std. Dev. & Min & Max \\
\hline AGEhh & 180 & 36.03 & 13.82 & 18 & 82 \\
\hline TFMZE & 180 & 5.03 & 2.32 & 1 & 18 \\
\hline EXP(years) & 180 & 10.52 & 6.99 & 1 & 38 \\
\hline TFRMLD(hect) & 180 & 0.63 & 0.36 & 0.06 & 3 \\
\hline ONFRMLD(hect) & 180 & 0.35 & 0.39 & 0 & 3 \\
\hline TLHOLD(TLU) & 180 & 5.18 & 8.16 & 0 & 52.25 \\
\hline OXENOWNED(TLU) & 180 & 0.84 & 1.06 & 0 & 5 \\
\hline DROAD(minute) & 180 & 13.11 & 14.56 & 1 & 60 \\
\hline DMKT(minute) & 180 & 147.78 & 64.14 & 40 & 300 \\
\hline
\end{tabular}

Source: Own computed from survey, 2021

Family size (TFMZE): The result from table 2 above show the average family size of the sample households was 5 persons, with minimum and maximum family size of 1 person and 18 persons, respectively.

Farming Experience (EXP): For producers with high farming experience their confidence to overcome the expected risk will be high. The result from descriptive statistics as shown in table 2 indicate the onion farming experience of sample households was 10.52 years at average with minimum of 1 year and maximum of 38 years respectively.

Total Farm holding size (TFRMLD): Another smallholder household characteristic which can depict the background of the smallholder household is the land holding size. The total farm size in this case includes all the farm land that smallholders owned both irrigable and non-irrigable land. Most of the respondents land holding size is below a hectare (ha) even if there are also those own smaller size less than 0.125 hectare. The result from descriptive statistics as indicated in table 2 above, the sample households land holding size was 0.63 hectare at average while the minimum and the maximum farm landholding was range from 0.063 and 3 hectares respectively.

The farm rented in by sample households during the survey year was also count as farm hold by respondent household. However, despite small farm land holding the producers benefit from Boset-Fentale irrigation project which enables them to produce two or three times per year.

Farm allocated for Onion (ONFRMLD): The result from descriptive statistics indicated in table 2 above show the farm land allocated for onion production by sample households was 0.35 hectare at average with 0.39 hectare of standard deviation. Indeed, the results show the minimum of 0 hectare i.e. No farm land allocated for onion production during survey year and 3 hectare of maximum allocation. Here also the farm rented in and produced onion during the survey year included in this size of onion allocated farm.

Livestock Holding (TLHOLD): Livestock production plays an important role at the study area. Total numbers of livestock holding of the households was measured in Tropical Livestock Unit (TLU). Livestock are used for various purposes. Use as sources of income, for crop cultivation and transportation of products. Livestock are also considered as a measure of wealth in the area. Farm households who have a number of livestock are considered as wealthy farmer in the farm community. As indicated in table 2 the average livestock holding of sample households was 5.18 with the standard deviation of 8.16 . The minimum holding size is 0 while the maximum are 52.52 in tropical livestock unit (TLU).

Number of oxen owned (OXENOWEND): Oxen use a farming household and help to plough the farm. Specially, in Ethiopia in general and at study area in particular smallholders commonly use oxen as draught power. The average oxen number owned by sample households were 0.841 in tropical livestock unit (TLU) while the minimum and maximum number of oxen owned by sample smallholders were 0 and 5 in TLU respectively.

Distance from all-weather road (DROAD): As indicated in table 2 above the residence of sampled households was located at average walking minutes of 13.11 away from all-weathers road. The minimum and maximum of sample households from all-weather road was 1 minute and 60 minutes respectively.

Distance from the nearest market (DMKT): As observed from table 2 the average distance needed for sample producer's to travel to reach the nearest market place where sold their products took an average walking minutes of 147.78 with the range of 40 and 300 minimum and maximum walking minutes respectively.

Sex of household head (SEXhh): The result from descriptive statistics of dummy variable as indicated in table 3 below 85\% (153) of sample household heads was male while the left 15\% (27) was female-headed households.

Education level of household head (EDUNhh): the author treated the educational status of household heads as categorical variable in this study. The result from descriptive statics as indicated in table 3 below show 33.8\% of sample household heads was unable to read and write while $15.9 \%, 22.8 \%, 12.2 \%, 12.7 \%$ and $2.6 \%$ of them have an education status of read and write, primary school (1-6), junior secondary (7-8), secondary (9-12) and tertiary (university or college) education level respectively. 
Table 3: Result of descriptive statics for categorical/dummy explanatory variables

\begin{tabular}{llcc}
\hline Variable & Response & Frequency & per cent \\
\hline SEXhh & Female & 27 & 15 \\
& Male & 153 & 85 \\
EDUNhh & Unable to read \&write & 61 & 33.8 \\
& Read \&write only & 29 & 15.9 \\
& Primary(1-6) & 41 & 22.8 \\
& Junior secondary(7-8) & 22 & 12.2 \\
& Secondary(9-12) & 23 & 12.7 \\
& Tertiary(university/college) & 4 & 2.6 \\
IRRGA & Yes & 167 & 92.8 \\
& No & 13 & 7.2 \\
CREDT & Yes & 54 & 30 \\
& No & 126 & 70 \\
EXSER & Yes & 61 & 33.9 \\
& No & 119 & 66.1 \\
MKTINFO & Yes & 139 & 77 \\
ONFINCM & No & 41 & 23 \\
& Yes & 41 & 23 \\
& No & 139 & 77 \\
\hline
\end{tabular}

\section{Source: Own computed from survey, 2021}

Irrigation access (IRRGA): Irrigation is the most important variable for production. Specially, at the study area the crops production mostly depends on the irrigation access as the area get low rainfall amount per year. As indicated by table 3 above the result from descriptive statistics show 92.8\% (167) of sample households was access to irrigation during the survey year while $7.2 \%$ (13) of sample households did not get irrigation service during the survey year. The sample households those not get irrigation during the survey year was produced other crops such as maize and teff with rain feed during main season.

Credit access (CREDT): Access to credit is also expected as one of the variables that positively influence onion output commercialization since access to credit enhance the purchase of inputs that use to increase their productivity. The result of descriptive statics shown in table 3 above indicate that out of the total sample households, $30 \%(54)$ of them was access to credit during survey year while 70\% (126) did not get credit service.

Access to Agricultural Extension service (EXTSER): The result of descriptive statistics show as indicated in table 3 above, during the production year of the survey undertaken, out of the total respondents $33.9 \%(61)$ of respondents were benefited from agricultural extension service while 66.1\% (119) were not benefited from extension service. This implies as majority of the respondents were not benefited from agricultural extension services in the area during the survey year.

Access to market information (MKTINFO): An access to market price information before delivering their product (onion) to the market help producers to benefit from their product. As indicated in table 3 the sample households get access to market information before delivering their onion product to market during the survey production seasons were $77 \%$ (139) while 23\% (41) of them did not get market information. Even though the majority of sample households were get market information during the survey production year the main source of their information was the brokers who make the information biased to benefit by themselves from the market price.

Non/off -farm income sources (ONFINCOM): As indicated in table 3 most of the sample households were depends on farm as the primary source of their income. Only $23 \%(41)$ of the sample households were participate on other additional income sources. The majority, 77\% (139) of the respondents did not benefit from participating in other income sources.

\section{Results from Econometric model Analysis}

Multicollinearity test: - A STATA software package (version 14) was employed to run the double hurdle model (probit regression at the first stage and truncated regression at the second stage). The model first checked for problems of multicollinearity and the result found no serious problem of multicollinearity.

\section{Determinants of onion market participation decision among smallholders farming households}

The probit regression model result show that the function of the participation decision in onion output was highly significant at less than $1 \%$ significance level (Prob $>$ chi2 $=0.0000$ ). This indicates as the model has strong explanatory power of independent variables to explain the factors determining the commercialization decision of smallholder households. The 0.657 value of Pseudo $\mathrm{R}^{2}$ show that, about $66 \%$ of the variation in decision to participate in onion output commercialization among the smallholder households were attributed to the hypothesized variables. 
Table 4 Result from Probit regression on onion market participation decision

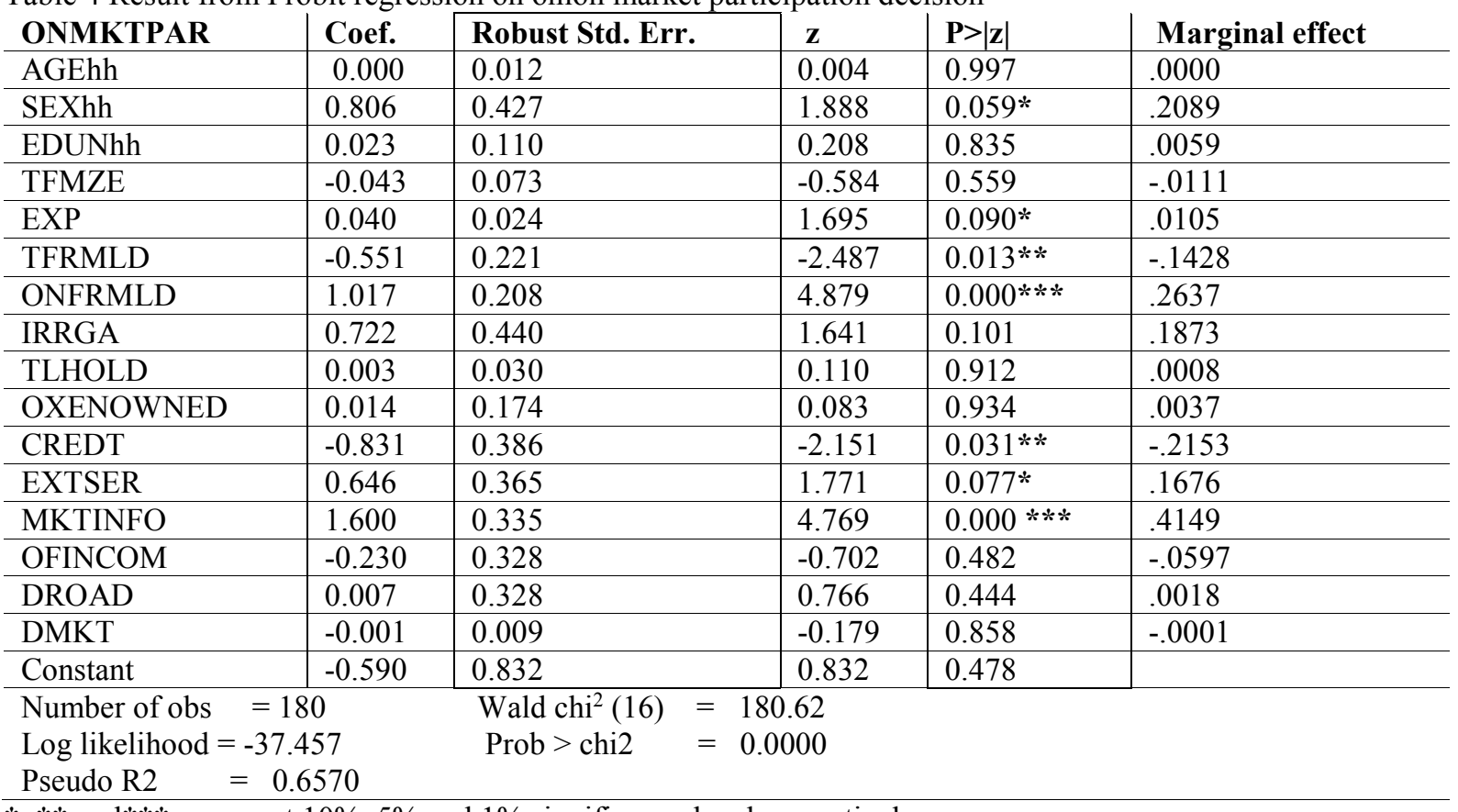

$*, * *$ and $* * *$ represent $10 \%, 5 \%$ and $1 \%$ significance level respectively.

Source: result from probit model, 2021

Out of 16 explanatory variables hypothesized to determine the onion market participation decision, seven of them were statistically significant and determine the decision of smallholders' onion market participation. These were the sex of household head, onion farming experience, total farm holding, farm allocated for onion production, credit access, access to extension and market information. Out of the seven independent variables these were statistically significant and influence the probability of the onion producers market participation decision, total farm holding size and credit access was significant in contrast direction of hypothesized while the others five variables were significant positively in expected direction.

Sex of household head (SEXhh) as indicated in table 4 above the sex of household head determine the onion market participation decision of smallholder farming household positively and statistically significant at $10 \%$. Furthermore, the result from marginal effect after probit indicate that being a male headed household increases the probability of participating in the onion market by $20.89 \%$ than the counter female headed household, keeping other factors constant. Besides, the qualitative information collected through Focus Group Discussion (FGD) show that, lack of initial cost and shortage of labour force were influence female headed households to engage in onion production at the area. This finding confirm with the finding of Wonduwossen and Bekabil (2014) which find as the male headed household increase the probability of crops output market participation and have positive effect on being commercial farmer .

Onion Farming experience of household (EXP) was also another explanatory variable that affect the market participation decision of smallholders' onion producers. In table 4 above the result from probit regression indicated that the farming experience of household was positively influence the probability to participate in the onion output markets and was statistically significant at $10 \%$ significance level. The marginal effect after probit also implies that as the farming experience of smallholder onion producers' increase by 1 year, the probability of deciding to participate in onion market increase by $1 \%$, hold the other factors constant. This implies that as farming experience increase, the perfection and self-confidence of producer also increase in which willingness to adopt new technologies that increase the productivity on another hand. This finding concurs with Kabiti et al. (2016) finding that reveals a unit increase in farming experience of the household head results in $2.97 \%$ unit increase in output commercialization. In contrary, the study conducted on smallholder farmers' crop commercialization in the highlands of eastern Ethiopia Ademe et al. (2017) reveals the experience in farming is found to be statistically significant and negative. The result justified as the younger household heads would engage in the markets probably because they are more dynamic to adopt new technologies that enhance productivity.

Total farm holding size (TFRMLD) as indicated in table 4 above, the regression result show that the farm size of sample households was significantly associated with households' onion market participation at less than 5\% significance level. In contrary to prior expectation, farm holding size was found to be negatively associated with smallholders' onion market participation and statically significant. Furthermore, the result from marginal effect after probit reveals that as the farm size of the household is increases by 1 hectare, the probability to participate in 
the onion output market decreases by $14.28 \%$, keep other variables constant. This finding implies that, as farm size of smallholder household increase the production shift to food crops rather than producing onion, then the onion market participation reduced. This result confirmed with research conducted by Toozoney (2017) on factors influencing commercialization of smallholder Tomato production in Zimbabwe, which revealed that holding other factors constant, a one-hectare increase in farm size was associated with a $2.93 \%$ decrease in Tomato commercialization. However, this result contrast with the result of study by Osmani and Hossain (2015) which reveals as the farm size increases, the probability of decision for commercialization increases.

Farm allocated to onion production (ONFRMLD) was the important variable that found to have a positive and significant influence on farmers' likelihood to participate in the onion output market at less than $1 \%$ level of significance. As indicated in table 4 above the result of marginal effect show a 1 hectare additional land the household allocate for onion crop would increase the farmers' likelihood of market participation by $26.37 \%$. The positive and significant relationships between the two variables indicate that land allocated for onion directly associated with onion productivity of household that in turn enhance onion output commercialization. This result was towards the result of study conducted by Mossie et al. (2020) which found land allotted to onion has positive and significant relation with amount of onion supply to market.

Access to credit (CREDT) was one of the variables that in contrary with the prior expectation and was negatively associated with the households' market participation decision. The result from probit regression indicated in table 4 above revealed that access to credit was negatively affect the market participation probability of onion producers household and statistically significant at less than 5\%. Moreover, the result of marginal effect show that keeping other variables constant, for smallholder household access to credit the probability of onion output market participation decrease by $21.53 \%$ than that of the counterpart no access to credit. This result implies that the smallholder households who took credit consider the credit as sources of income to buy agricultural inputs then divert the production to food crops for home consumption and sell surplus rather than cash crop while the household not access to credit obligated to produce cash crop like onion to get income source enable them to buy agricultural inputs. The data from focus group discussion also show that smallholder household access to credit fear risk of price fluctuation and disease to produce onion rather they engaged in other business work.

Access to extension service (EXTSER) was positively associated with households' onion market participation decision at less than 10\% significance level. From marginal effect after probit as the result indicated in table 4 above, holding others variable constant, the smallholders who benefited from extension service likely participate more in onion output by $16.76 \%$ than the counterpart not benefited from the extension services. This implies that households' contact with extension agents increases their production and productivity by using provided training and advisory services. This study is in line with the finding of Regasa et al. (2019) conducted on determinants of smallholder fruit commercialization in Southwest Ethiopia which point out that frequency of extension contact was statistically significant and positively influenced the market participation decision of the households. Another study finding by Abrha et al. (2020) revealed that extension contact is related to access to formal training and informal on onion production and marketing for producer farmers. The positive and significant relationship indicates that extension contact had improved onion farming household ability to acquire new technology and capacity of production, which in turn improves productivity and thereby increase marketable supply of onion. In contrary, the finding of study by Melese et al. (2018) point out that extension access was negatively and significantly associated with onion market participation. The possible reason could be due to those who have access to the extension service and do not appropriately apply the techniques and advices suggested by the extension agents such as the way using fertilizers, herbicides and pesticides would cause their production to reduce or damaged.

Access to market information (MKTINFO) was as prior expectation, it found to have positive and significant influences on the farmers' participation decision in the onion output commercialization at less than $1 \%$ significance level as indicated in table 4 above. The marginal effect of this variable after the probit regression disclosed that as farmer's has access to market information the probability of participation decision in the onion output commercialization increases by $41.49 \%$, keeping all other factors constant. This implies that access to market information enhance the producers to be able to get their products to market during the high market price and receive equitable price treatment. Farmers need information pertaining to output prices so as to make the right decision, ahead of the production season, regarding which type of crops to produce and sell. This indicates that access to market information helps farmers' to be market oriented for their production (when and where to sell). The study finding by Apind (2015) revealed that the source of market information increased the chance that a farmer would sell rice in Kenya.

Determinants of smallholders' onion market participation level

The level of smallholders farming onion out market participation is measured in sells value of onion crop. Only the smallholder sample households who sell onion during the survey year of production are considered in this step of analysis. 
Table 5: Result from truncated regression of determinants of onion market participation level

\begin{tabular}{|c|c|c|c|c|}
\hline VLUESOLD & Coef. & Robust Std. Err & $\mathbf{Z}$ & $\mathbf{P}>|\mathbf{z}|$ \\
\hline AGEhh & 1090.57 & 429.233 & 2.541 & $0.011 \% *$ \\
\hline SEXhh & 34889.75 & 15699.77 & 2.222 & $0.026 * *$ \\
\hline EDUNhh & 162.26 & 2222.41 & 0.073 & 0.942 \\
\hline TFMZE & -2602.05 & 1952.84 & -1.332 & 0.183 \\
\hline EXP & -307.05 & 745.09 & -0.412 & 0.680 \\
\hline TFRMLD & 5906.67 & 4256.70 & 1.388 & 0.165 \\
\hline ONFRMLD & 13880.13 & 4925.27 & 2.818 & $0.005 * * *$ \\
\hline IRRGA & 42549.30 & 25560.63 & 1.665 & $0.096 *$ \\
\hline TLHOLD & 460.30 & 342.72 & 1.343 & 0.179 \\
\hline OXENOWNED & 10764.76 & 3094.96 & 3.478 & $0.001 * * *$ \\
\hline CREDT & 16629.83 & 14566.81 & 1.142 & 0.254 \\
\hline EXTSER & 8746.79 & 13909.70 & 0.629 & 0.529 \\
\hline MKTINFO & 20910. & 16942.88 & -1.234 & 0.217 \\
\hline OFINCOM & -1191 & 10759.91 & -1.103 & 0.270 \\
\hline DROAD & 25.487 & 316.09 & 0.081 & 0.936 \\
\hline DMKT & 132.169 & 64.52 & 2.049 & $0.040 * *$ \\
\hline Constant & $-1.05 \mathrm{e}+05$ & 34826.17 & -3.015 & 0.003 \\
\hline \multicolumn{5}{|c|}{ Log likelihood $=-1580.369 \quad$ Prob $>$ chi $^{2}=0.0000$} \\
\hline
\end{tabular}

$*, * *$ and $* * *$ represent at $10 \%, 5 \%$ and $1 \%$ significance level respectively

Source: own computed from model, 2021

As indicated by table 5 above, out of 16 variables expected to influence the level of smallholder households' onion market participation, six of them were statistically significant.

Age of household head (AGEhh) was found to be positively influences the onion market participation level at 5\% significance level as indicated in table 5 above. The coefficient of the age show that an increase by 1 year in the age of household head, the proportion of the value of onion sold increase by 1090 ETB. This implies that the older household heads have more experienced and have taken confidence to apply new technologies that increase the onion production and increase the level of value get from onion sold compared to the counter younger household heads. The data from FGDs was also indicate that younger people are move to town to search job in industrial/services sector and not willing to stay in agricultural sector hence their onion market participation levels become lower when compare with elder. The finding of this study is in line with the finding of Martey et al. (2012) that found increasing in the age had a positive effect on the commercial index of a farm household. Older farmers tend to be more commercialized because they are able to make better production decisions and have greater contacts which allow trading opportunities to be discovered at a lower cost than younger ones. In contrast study by Seyoum et al. (2011)was found the negative influences of age on groundnut commercialization intensity at $1 \%$ significance level. This implies that active labour force in agricultural product is more actively engaged in groundnut supply to the market as compared to their older counterpart.

Sex of household head (SEXhh) variable was found to be positive and statistically significant influence on the level of onion market participation in value of sold at 5\% level of significance as indicated in table 5 above. The positive sign show that male headed household significantly earn 34,889 ETB more from selling onion to market than that of female-headed households, keeping other variables constant. This implies that female headed household influenced by shortage of initial working capital and labour to produce onion and highly participate in the markets at the study area. This finding confirmed with finding of Hailu (2017) on potato commercialization that reveal the positive influence of sex of household head. The reason behind male headed households supplied more potato to market than female headed households, is that females can take higher care than males about households consumption by saving from produce to feed household; this can reduce the quantity to be sold. Another Study conducted by Mossie et al. (2020) on Econometric analysis of onion marketed supply in Northwest Ethiopia also confirmed that being male head household significantly increase onion quantity supplied to the market by 2.719 quintals as compared to that of female headed households, keeping other variables constant.

Farm allocated to onion (ONFRMLD) was one of the variables that influence the level of the value of onion marketed positively. The result show that the land allocated to onion has significant effect on value of sales of onion at $1 \%$ significant level with expected positive sign. The regression coefficient show that as indicated in table 5 above a hectare increase in farm allocated to onion production increase the value get from onion sold by 13,880 ETB, holding other variables constant. This implies that more farm land allotted to onion production increase the production volume of onion which in turn increase the value from sold of onion. Others studies by Melese et al. (2018) also confirmed with this finding that found land allotted to onion has positive and significant 
relation with amount of onion supply to market.

Access to irrigation (IRRGA) was also found to be positive and statistically significant implication on the value of onion output sold at 10\% significance level in prior expected sign. The coefficient of truncated regression show that households with access to irrigation earn at average about 42,549 ETB more than those households produce with rain fed, keeping constant other variables. This implies that households with access to irrigation produce two or three times per year and benefited more from onion selling than who produce with rainfall. That means smallholder onion producers with access to irrigation have more opportunities to supply more onion products than farmers without access to irrigation due to improvement in onion cropping intensity and economies of scale. The result of finding by Tufa et al. (2014) also confirmed with this finding which found irrigation was positive and statistically significant implication on the value of horticultural output sold at $1 \%$ level.

Number of oxen owned (OXENOWNED) statistically significant and positively influence the level of smallholder household market participation level at $1 \%$ significance level as indicated in table 5 above. Moreover, the coefficient of regression show the one unit increase in the number of oxen owned by smallholder household the level of onion sold to market at average (in value) increase by 10,764 ETB, keeping other variables constant. This implies that oxen use as draught power especially for smallholder farming households, having more oxen enable to produce more and increase market participation level. The focus group discussion participants also explained that even the household with no or small pilot of farm but have oxen rent in farm and produce onion in which enhance their income. The results of finding by Hailua et al. (2015)agree with this result as draught powers positively and significantly influence crops commercialization.

Distance to the nearest market (DMKT) was the variable affect the level of onion market participation in contrary to the prior expectation. As indicated in table 5 it was statistically significant and positively affects the level of onion market participation at $10 \%$ significance level. The regression coefficient show that by maintaining other variables constant, when the number of a walking minute to the nearest market increases by one minute the level of onion output marketing also increase by $132 \mathrm{ETB}$ at average in value sold. This due to reason that as the distance from market of household increase they took whole their product at once to reduce the transition cost which in turn increases the volume of onion marketed. Long distance from market increases the cost of transportation. The producers take the product all at once that increase their level of market participation to reduce transaction cost. This result agree with the finding of Melese et al. (2018) which found that an increase in distance from house to nearest urban market in kilometre indicated an increase in the probability of onion market participation by $2.2 \%$. The reason is that it is likely better non-farm employment opportunities in addition to farming activity for households close to the markets may account for their smaller reliance on onion sale.

\section{CONCLUSION}

Smallholder farming household's onion output market participation decision and the level of participation is affected by socio- economic, institutional and market factors. Therefore, clearly identify this factors helps the producers to enhance their production and benefit from output in one way and also satisfy the consumers demand in another way. Access to irrigation water is the crucial issue and have unrepresentative role to produce crops both for home consumption and market at the study area. Hence, there is the need to establish more main canals or improve farmers' accessibility to reliable irrigation water to increase the production of market oriented crops like onion.

\section{References}

Abrha, T.Emanna, B. and Gebre, G. G. (2020). Factors affecting onion market supply in medebay zana district, tigray regional state, northern ethiopia. Cogent Food \& Agriculture, 6(1), 1712144.

Ademe, A.Legesse, B.Haji, J. and Goshu, D. (2017). Smallholder farmers crop commercilization in the highlands of eastern ethiopia. Review of Agricultural and Applied Economics (RAAE), 20(1340-2018-5165), 30-37.

Agumas, Y. (2019). Determinants of onion production in fogera district, south gondar zone

Alemu, D. andBerhanu, K. (2018). The political economy of agricultural commercialisation in ethiopia: Discourses, actors and structural impediments.

Alemu, D. andBishaw, Z. (2015). Commercial behaviours of smallholder farmers in wheat seed use and its implication for demand assessment in ethiopia. Development in Practice, 25(6), 798-814.

Ali, D. A.Deininger, K. and Harris, A. (2016). Large farm establishment, smallholder productivity, labor market participation, and resilience: Evidence from ethiopia. World Bank Policy Research Working Paper(7576).

Apind, B. O. (2015). Determinants of smallholder farmers market participation; a case study of rice marketing in ahero irrigation scheme Egerton University].

Baltissen, G. andBetsema, G. (2016). Linking land governance and food security in africa. Outcomes from Uganda, Ghana, Ethiopia.

Bedaso, T.Wondwosen, T. and Mesfin, K. (2012). Commercialization of ethiopian smallholder farmer's production: Factors and challenges behind. Paper presented on the Tenth International Conference on the 
Ethiopian Economy, Ethiopian Economics Association,

Bekele, A. andAlemu, D. (2015). Farm-level determinants of output commercialization: In haricot bean based farming systems. Ethiopian Journal of Agricultural Sciences, 25(1), 61-69.

Boka, G. T. (2017). Climate change challenges, smallholders' commercialization, and progress out of poverty in ethiopia. Working Paper Series(253).

Etafa, A. (2016). Smallholder agro-pastoralists commercialization of major crop (maize and onion) in fentalle district: The case of boset-fentalle irrigation scheme, ethiopia. Age, 109(35.7), 9.3.

Fischer, E. andQaim, M. (2012). Linking smallholders to markets: Determinants and impacts of farmer collective action in kenya. World development, 40(6), 1255-1268.

FWPADO. (2018). Fentale woreda pastoral and agro pastoral development office report, unpublished.

Gebremedhin, B. andJaleta, M. (2010). Commercialization of smallholders: Is market participation enough?

Gebreselassie, S. (2003). Helping small farmers to commercialize: Evidence from growing onion and tomatoes for sale in central ethiopia. A Research Update of the Future Agricultures Consortium.

Gyau, A.Mbugua, M. and Oduol, J. (2016). Determinants of participation and intensity of participation in collective action: Evidence from smallholder avocado farmers in kenya. Journal on Chain and Network Science, 16(2), 147-156.

Hailu, A. (2017). Determinants of volume sales among smallholders potato farmers in ejere district, west shoa zone, oromia region of ethiopia. Journal of Economics and Sustainable Development, 8(5), 87-95.

Hailua, G.Manjureb, K. and Aymutc, K.-M. (2015). Crop commercialization and smallholder farmerslivelihood in tigray region, ethiopia. Journal of Development and Agricultural Economics, 7(9), 314-322.

Jaleta, M.Gebremedhin, B. and Hoekstra, D. (2009). Smallholder commercialization: Processes, determinants and impact.

Kabiti, H.Raidimi, N.Pfumayaramba, T. and Chauke1, P. (2016). Determinants of agricultural commercialization among smallholder farmers in munyati resettlement area, chikomba district, zimbabwe. Journal of Human Ecology, 53(1), 10-19.

Martey, E.Al-Hassan, R. M. and Kuwornu, J. K. (2012). Commercialization of smallholder agriculture in ghana: A tobit regression analysis. African Journal of Agricultural Research, 7(14), 2131-2141.

Melese, T.Dessie, A. B. and Abate, T. M. (2018). Determinants of commercialization by smallholder onion farmers in fogera district, south gondar zone, amhara national regional state, ethiopia. Journal of Development and Agricultural Economics, 10(10), 339-351.

Mossie, H.Berhanie, Z. and Alemayehu, G. (2020). Econometric analysis of onion marketed supply in northwest ethiopia. Cogent Food \& Agriculture, 6(1), 1733329.

Muricho, G.Manda, D.Sule, F. and Kassie, M. (2017). Smallholder agricultural commercialization and poverty: Empirical evidence of panel data from kenya.

Nigussie, A.Kuma, Y.Adisu, A.Alemu, T. and Desalegn, K. (2015). Onion production for income generation in small scale irrigation users agropastoral households of ethiopia. Journal of Horticulture, 1-5.

Osmani, A. G. andHossain, E. (2015). Market participation decision of smallholder farmers and its determinants in bangladesh. Економика пољопривреде, 62(1).

Pender, J. L. andAlemu, D. (2007). Determinants of smallholder commercialization of food crops: Theory and evidence from ethiopia.

Poulton,C. (2018). Apra brief 1: What is agricultural commercialisation: Who benefits and how do we measure it?

Regasa, G.Negash, R.Eneyew, A. and Bane, D. (2019). Determinants of smallholder fruit commercialization: Evidence from southwest ethiopia. Review of Agricultural and Applied Economics (RAAE), 22(1340-20193718), 96-105.

Seyoum, C.Lemma, T. and Karippai, R. S. (2011). Factors determining the degree of commercialization of smallholder agriculture: The case of potato growers in kombolcha district, east hararghe, ethiopia.

Sokoni, C. H. (2008). Commercialisation of smallholder production in tanzania: Implications for sustainable resources management. The geographical journal, 174(2), 158-161.

Tilaye, B. (2010). How to involve smallholder farmers in commercial agriculture/horticulture. Ethiopian horticulture producers and exporters association, Ethiopia, Addis Ababa.

Toozoney, T. (2017). Factors influencing commercialization of smallholder tomato production: Case of University of Zimbabwe].

Tufa, A.Bekele, A. and Zemedu, L. (2014). Determinants of smallholder commercialization of horticultural crops in gemechis district, west hararghe zone, ethiopia. African Journal of Agricultural Research, 9(3), 310-319.

Wondowussen, D. andBekabil, F. (2014). Determinants of fruit and vegetable commercialization among rural households: The case of bora district, east showa zone, oromia region St. Mary's University]. 